\title{
The public and economic aspects of the functioning of protected areas within a commune
}

\begin{abstract}
Between 2009 and 2013, research was conducted in the commune offices for the Podlaskie voivodeship which have large areas of protected Natura 2000 sites. The research is repeated every few years and widened to include new communes. The aim of the research was to determine the influence of the protected areas on the economic conditions of the communes. It is widely assumed that protected areas generate income for communes, however the communes claim that they incur large additional costs. The surveyed communes were critical of obligatory legal requirements in relation to the protected areas. It was argued that there are problems with obtaining natural resources and with the establishment of new summer resorts, residential and farm buildings and infrastructure; as well as the use and management of the site. The communes' benefits incidental to the ownership of the protected area are not clear. As part of the benefits, the protected areas offer an opportunity for tourism development. According to the communes, protected areas generate losses in which the estimated losses are several times higher than the potential income. Studies indicate that the conservation cost factor should be considered in terms of financing the communes from the state budget.
\end{abstract}

Keywords

Nature 2000 site $\cdot$ national park - local self-government - questionnaire form $\cdot$ costs of exercising the protection

(C) University of Warsaw - Faculty of Geography and Regional Studies

Introduction

Podlaskie voivodeship is distinguished by a large number of established protected areas. 18 Natura 2000 sites operate there. These consist of Special Protection Areas (SPAs) with an area of 790.38 thousand hectares, and Special Areas of Conservation (SAC) with an area of 286.51 thousand hectares. There are also four national parks with a total area of 92.09 thousand ha., 91 nature reserves with an area of 23.61 thousand ha., three parks with an area of 88.08 thousand ha., and 15 protected landscape areas with a total area of 462.72 thousand ha. In the design, the Natura 2000 site is a nature protection system that combines effective protection of Europe's most precious ecosystems and species of plants and animals, with respect for property rights and the rights of local communities to sustainable development (Tederko 2010).

The establishment of the protected areas and the resulting legislative obligation of adapting local government and local people to the prohibitions and rules, induces different feelings and opinions about these areas. These are mostly negative views (Bołtromiuk 2011). Restrictions apply to investments in the vicinity of protected areas, thereby limiting opportunities for development and reducing the income received by the commune (Czarnecki 2011). The functioning of protected areas can be an element of economic development of the area through the development of tourism and other activities using attributes of the natural environment (Łuszczyk 2011; Christ et al. 2003). The Natura 2000 sites protect traditional agriculture, valuable natural habitats and the development of organic farming (Pawluśkiewicz \& Piekut 2011,
Henryk Jaros

Department of Environmental Protection and Managemen

Bialystok University of Technology

e-mail: henrykjaros@poczta.onet.pl

Received: 3 September 2014

Accepted: 21 November 2014

Pagiola et al. 2004). They are also the reason for launching subsidies for agricultural production within the agri-environment measures. Having a very high proportion of protected areas within the communes belonging to Podlaskie voivodeship must have an impact on the functioning of the region and on the individual communes (Jaros 2004). It happens that the whole of a commune's area can be occupied by protected areas. There are many communes in the region where protected areas occupy 20 to $80 \%$ of the total area of the commune. An important issue is the identification and evaluation of social and economic phenomena arising from the functioning of large protected areas.

\section{Material and methods}

Research on the operation of Natura 2000 sites and national parks within the structure of local government areas, and the evaluation of the existing organizational solutions (legal and economic), were based on surveys sent to 10 commune offices of Podlaskie voivodeship (Kuczyńska 2009). Some villages were selected for having, within their borders, large areas of Natura 2000 sites. The study was conducted in the following communes. - Suwalki - protected areas cover $39 \%$ of the total area of the commune. These are: Special Area of Conservation (PLH200004), (PLH200006) and Special Protection Area (PLB200002);

- Grajewo - Protected areas cover $48 \%$ of the total area of the commune. These are: Special Protection Area (PLB200006) and Special Area of Conservation (PLH200008); 
- Goniądz - Protected areas cover $75 \%$ of the total area of the commune. These are: Special ProtectionArea (PLB200006) and Special Area of Conservation (PLH200008);

- Gródek - Protected areas cover $91 \%$ of the total area of the commune. These are : Special Protection Area (PLB200003) and Special Area of Conservation (PLH200006);

- Michałowo - Protected areas cover 30\% of the total area of the commune. These are: Special Protection Area (PLB200007), (PLB200003) and Special Area of Conservation (PLH200010), (PLH200006);

- Sokoły - Protected areas cover $9 \%$ of the total area of the commune. These are: Special Protection Area (PLB200001) and Special Area of Conservation (PLH200002);

- Narewka - Protected areas cover $80 \%$ of the total area of the commune. These are: Special Protection Area (PLC200004), (PLB200007) and Special Area of Conservation (PLH200001);

- Białowieża - Protected area covers $100 \%$ of the total area of the commune. This is: Special Protection Area (PLB200004);

- Orla - protected area occupies $9 \%$ of the total area of the commune. This is: Special Protection Area (PLB200004);

- Mielnik - protected areas cover $8.6 \%$ of the total area of the commune. These are: Special Protection Area (PLH140001) and Special Area of Conservation (PLH200014), (PLH140011).

A survey was carried out in 2009 and the results of these studies are the subject of this analysis. These studies are continuing while also expanding the number of communes included in the study. The scope of the collected and compiled information is also extended. The study was expanded to include issues relating to planning and research costs incurred by the communes in respect to the ownership of the protected sites in their area. Each year the number of communes covered by the study, and the nature and scope of the research together with the nature and scope of material for evaluation, is increasing.

The survey was addressed to the communes' authorities, in which we posed a question about the current and potential benefits resulting from the fact of having protected sites on the communes' area. The questions also concerned the difficulties in managing and conducting investment policy, community planning, and the perception of protected areas by the local population.

In 2013, as a part of continuing research, the mayor of Trzcianne commune was interviewed. He calculated the costs incurred by the commune and the local population for the functioning of the Biebrza National within their boundaries (Dabrowski 2013). Within the limits of the commune there is "Basen Dolny" in Biebrza National Park as well as the Natura 2000 site Special Protection Area "Ostoja Biebrzańska" (PLB200006) and Special Area of Conservation "Dolina Biebrzy" (PLH200008). Protected areas cover $50 \%$ of the total area of the commune. A large share of protected land in the general area of the commune must influence the way the economy and the commune is administered. The interview concerned an assessment of functioning legal and economic conditions and the effects on the finances of the commune and on public perception. The evaluation was made on the basis of the commune's administration, estimated loss and income and that of its inhabitants, arising from the functioning of protected areas.

\section{Results}

The answers given by the mayors of the communes taking part in the survey, or people designated by them, were grouped into three categories; yes, no, and I do not know. In the survey there were also questions that could have been answered in the form of an opinion on the matter.
The surveys show that all communes have knowledge about the establishment and functioning of protected areas within their commune. This knowledge is shared by both the local authority and its residents. In $80 \%$ of the statements it was indicated that the authorities and the residents have good access to information relating to the functioning of Natura 2000 sites. In $20 \%$ of opinions access was rated as inadequate.

In cases concerning opinions on the positive role and satisfaction resulting from the establishment and operation of protected areas within the commune, there was no positive opinion. Negative opinions comprised $40 \%$, and the remaining $60 \%$ of opinions didn't have a clearly specified position.

The lack of positive comments about the establishment of protected areas within the commune results from the anxiety of authorities and inhabitants concerning various constraints arising from the functioning of protected areas. The concerns relate to restrictions on the functioning of the commune and investment opportunities. They occurred in all responses ( $100 \%$ of opinions), but not in all cases were there legitimate arguments. We found that $60 \%$ of the respondents had knowledge based on the documents related to the functioning of the protected areas. In $10 \%$ of respondents fear arose from common beliefs and opinions - without justification, while in $30 \%$ of cases knowledge about the subject varied with the scope of the source of that knowledge: partially understood facts and general opinions.

Protected areas (Natura 2000 sites and National Parks), were also perceived as a factor in limiting the development of the region. Such opinions were expressed by $30 \%$ of respondents.

The fear concerning the effects of restrictions on the functioning of the commune influenced the responses related to the purpose and need for establishing Natura 2000 protected areas. In $40 \%$ of cases there was a positive ruling on the idea of creating Natura 2000 sites. In 10\% of cases, statements were clearly negative and in $50 \%$ of cases the views were mixed. The ambiguity of the responses caused a separation of the issue into two parts -1 ) the idea and purpose of creating protected areas was not questioned, and 2 ) responses that were strongly opposed to the idea of creating protected areas in their own commune. The concerns expressed in the above opinions have occurred with full or partial knowledge of the benefits to the community arising from the ownership of protected areas. In $30 \%$ of cases there was full knowledge about the possibility of achieving different types of benefits, while in $70 \%$ of cases this knowledge was not complete and was based on media messages and popular opinions.

The authorities in almost all the communes assessed that the local community has a negative attitude towards the functioning of their protected areas. In $40 \%$ of cases the local community has a negative view of protected areas; in $50 \%$ of cases public opinion, according to the authorities of the commune, is negative but not dominant; and in $10 \%$ of views the communes' authorities were unable to determine public sentiment on the issue.

The communes' authorities perceive that the reasons for the negative public sentiment is in the lack of easy access to simple but clear information on the functioning of protected areas. There is no information about the restrictions imposed on these areas and the principles of investing in the surrounding areas. One of the ten analysed communes based its fear concerning restrictions, on the sourcing of natural assets, formation of new summer resort, residential and farm buildings as well as restrictions on the conduct and modernization of roads, land development opportunities and infrastructure development. According to the respondents, restrictions on development and investment contribute to a local increase in unemployment. These are extreme conclusions, not resulting from facts that can be analysed, but existing in the minds of authorities. 
The communes' and local community's fear of the various constraints is part of the problem. Another important element, however, is the relationship between negative consequences that are feared by the communes' authorities and residents, and community benefits that arise out of ownership of protected areas. The survey has tried to obtain objective information on the communes' benefits directly arising from the functioning of the protected site. Benefits received by the commune were not in all cases associated with protected areas (as the source for these benefits). One of the questions on the form was as follows: - "does the community use different sources of financing for the Natura 2000 sites?", None of the communes has indicated a positive response. Eight communes stated that they do not have any benefits with regard to Natura 2000 , one commune was not able to determine its position and one commune concluded that there is insufficient information about the possibilities of achieving such benefits, which suggests a lack of awareness that special financing is available for Natura 2000 sites.

A communes' benefits connected with ownership of the protected area most often occur in a form hidden from the none too keen observer. One of the possible benefits is the implementation of environmental investment opportunities, which are commonly associated with the overall national environmental policy. It is true that the factor of environmental policy is the main tool for the possibility of obtaining funding for the ecological communes' tasks, but the ease and priority of access to these resources already result from the ownership of protected areas. This factor is not recognised by some communes. In $80 \%$ of the surveyed communes environmental investments had been implemented and only $20 \%$ had not taken such action up until the day of analysis. This result is opposite to the result of the previous question. It should be assumed that the communes do not combine the possibilities of obtaining financial resources with the functioning of the protected areas on their terrain. Environmental investments in communes consist of: air protection, waste management, water protection, nature protection, conservation, commune green areas maintenance, education, and environmental protection. Financial resources for these tasks are derived mostly from the National or Regional Fund for Environmental Protection and Water Management.

Communes' authorities are divided on the issue of treating the protected area as an initiating factor in local development. In 50\% of cases there is no intention of making any development efforts using protected areas. The reason for this attitude is a lack of financial resources for developmental actions, belief in limiting the role of the protected area in the development process, and a lack of ideas for this type of project. In other cases, $40 \%$ of respondents planned to take advantage of the presence of the protected area in order to improve water and wastewater management, and in $10 \%$ of cases planned development for tourism.

There is a strong reluctance to create new protected areas in communes. When asked about this issue the responses were as follows: in $70 \%$ of cases an answer was not given, in $20 \%$ of cases the statement was ambiguous and in $10 \%$ of cases the idea of creating a new protected area was initiated with very clearly defined rules with the ability to achieve specific benefits for the community and the local population.

Opinions were also divided in terms of location problems for investment projects in the vicinity of the protected area. In $40 \%$ of cases it was argued that the placement of investment projects in the vicinity of the protected area is possible and the same percentage had the opposite view. In $20 \%$ of cases the answers were not clear because it was claimed that some problems may occur but not in all types of investments.

Protected areas are also perceived as a factor in triggering subsidies for agricultural production under agri-environment schemes. This element is considered positive. It is emphasized that payments under environmental programs strengthen traditional agriculture, which should continue to function in the Polish countryside.

An unexpected result is the ambiguity of communes' authorities statements on the role of Natura 2000 sites in the development of tourism. Only one statement (10\%) stressed the crucial role of protected areas in the development of tourism, while $50 \%$ of respondents rated these areas as having varying degrees of influence on the development of tourism and in $40 \%$ of cases it was found that there is no direct connection between the presence of protected areas in the community and the development of tourism. One community has developed a justification for its position by claiming that protected areas are appreciated by foreign tourists and that they encourage them to visit, whereas for domestic tourists, protected areas are not particularly attractive and would not be the main reason for planning their holidays.

There is ambiguous interpretation of the obligations for introducing constraints on management plans for Natura 2000 sites and national parks in local planning documents. In $60 \%$ of cases there is a full awareness that the principles of management and usage of land under legal protection, which are contained in these conservation area plans, need to be moved into the community planning documents. In $30 \%$ of cases it is believed that this requirement is not clear and in $10 \%$ of cases it is believed that such an obligation does not exist. Due to the different interpretations of the applicable laws, we observe, in practice, discrepancies between the records contained in the documents and the actual activities of the commune in everyday tasks.

Regarding procedures and methods for creating the Natura 2000 areas, communes were consistently claiming that these areas have been created without the consent and knowledge of local government. They just received information about the decision taken by the government on the matter. These areas have been established on the basis of existing natural assets without taking into account local social and economic conditions of the area. Adoption of such an approach is clearly criticized .

The fact of failing to take into account the social and economic conditions of the commune in which Natura 2000 sites, or other forms of protection, were created is supported by a thorough analysis of the communes' costs and benefits. Such a calculation was made by Trzcianne community, which has protected areas covering $50 \%$ of the commune. The results of this calculation should be a signal to take administrative action for compensation for actual financial losses incurred by the commune. The balance of profit and loss should be verified for accurate measurement indicators and unit costs, but the principle of running cost calculations for functioning protected areas is just and makes economic sense.

The commune's losses resulting from the creation of protected areas resulted from:

1. The creation of the National Park causes a change in the tax status for forests located within the park. The forest tax rate is reduced by $50 \%$ and is a loss for the commune's income, depending on the area of protected forest.

2. Prior to the establishment of the National Park in Trzcianne the forestry management industry was employing about 30 people from the Trzcianne commune. The change in forest management within the National Park resulted in a reduction in employment level to 7 people.

3. Prior to the establishment of the National Park, facilities associated with acquisition, transportation and processing of wood, employed about 70 people from the Trzcianne commune. At present there is no employment or it occurs only occasionally. 
4. Prior to the establishment of the National Park about 550 families benefited from the ability to obtaining cheap firewood in the forest district but now this option is no longer available.

5. Prior to the establishment of the National Park, a source of additional income for about 120 families was the harvesting of a undergrowth. This was a fixed income for these families.

Currently there is a ban on the collecting of undergrowth and therefore the income has gone. This item of balance sheet losses may be the subject of an error.

The estimated annual losses of the commune and its residents, resulting from the above balance sheet losses, are at the level of PLN 1,465,000.00.

Losses also occur at other stages:

6. There is crop and tree-stand losses resulting from a significant increase in the population of beavers, moose and wild boar. Losses incurred from wild game are recorded and compensated but they do not cover the actual losses. In the case of small damage they are not reported. The scale of this phenomenon is as follows:

- damages caused by beaver - occurs on more than 300 farms,

- damages caused by moose - occurs in about 100 households,

- damages caused by wild boar - occurs in more than 150 farms.

The total amount of losses incurred by the residents of the commune is approximately PLN 1,100,000.00 per year.

7. The lack of maintenance on the river Biebrza and Kosódka and the lack of drainage facility maintenance in the National Park results in the flooding of more than 3,000 acres of meadow used by the residents of the commune.

These losses are approximately PLN 3,000,000.00 per year.

The community's income resulting from the functioning of the protected area was also estimated. The factors resulting in additional revenue for the commune and its residents are:

1. Subsidies for agricultural production under agri-environment schemes.

2. The emergence of 11 agri-tourist farms.

3. The emergence of the "Dwór Dobarz" guesthouse.

4. Increase in the attractiveness of the commune.

5. Promotion of the commune.

The estimated revenue for the commune and its residents is about PLN 1,100,000.00 per year.

The estimated annual economic balance of the functioning of the protected area in Trzcianne commune is as follows in Table 1.
The commune's calculations can be discussed in terms of estimating the parameters that form the magnitude of losses or in terms of income distribution. The final result could be slightly different, but that does not change the fact that there is a feeling in the communes of incurred losses arising from the functioning of protected sites in their area. That is sufficient reason for thinking about solving the problem.

\section{Research results summary and discussion}

The surveyed communes were critical of the mandatory legal and economic considerations as well as the method of creating new protected area. In the commune's opinion the Natura 2000 sites have been determined solely on the basis of natural terrain, without taking into consideration the economic and social aspects together with the opinion of the local authorities and its population.

In some communes it has been claimed that the close proximity of national parks or areas of Natura 2000 sites is a limiting factor in the development of the commune. A significant number of communes opposed the creation of new protected areas while the remaining communes did not define their positions unequivocally. All the surveyed communes are concerned about the limitations resulting from the rules of exercising the protection of Natura 2000 sites and national parks. Among the concerns mentioned are problems associated with obtaining natural resources within the limits of protected areas, restrictions on building development, modernization of roads, infrastructure, usage and management of the site, as well as major impediments to the implementation of tasks resulting from the local zoning plan.

Benefits connected with the ownership of land conservation are not always recognised by the commune. In rare cases communes use protected areas as a factor enabling them to gain external funds for development. However, most communes do not use this option. . It is noted, however, that protected areas can contribute to the development of tourism.

Calculations made in Trzcianne indicate that protected areas generate financial losses for the commune and its inhabitants. The balance of profit and loss indicated that losses are several times higher than profits. The resulting balance may not be fully accurate but it indicates that conservation costs, and we need to take this factor under consideration in terms of financing communes from the state budget. The solution to this problem could be environmental subsidies from the state budget which would eliminate the losses and improve the public opinion of protected areas.

\section{Conclusion}

1. The Communes' authorities were critical of the method for creating the Natura 2000 sites and of the current legal requirements in those areas.

Table 1. Incomes and losses for the commune resulting from the functioning of protected areas

\begin{tabular}{|c|c|}
\hline Income & Loss \\
\hline $\begin{array}{l}\text { 1. Surcharge for agricultural production. } \\
\text { 2. Development of agri-tourism. } \\
\text { 3. The emergence of tourism investment. } \\
\text { 4. Increase in the communes attractions. } \\
\text { 5. Promotion. }\end{array}$ & $\begin{array}{l}\text { 1. Forests tax reduction. } \\
\text { 2. Employment reduction in forests. } \\
\text { 3. Employment reduction in the obtaining and processing of wood. } \\
\text { 4. The inability to buy cheap firewood. } \\
\text { 5. Lack of incomes from undergrowth harvesting. } \\
\text { 6. Damage from the increased population of wild game. } \\
\text { 7. Loss of crop (due to flooding of the area. }\end{array}$ \\
\hline Sum $=$ PLN 1.100.000,00. & Sum $=$ PLN 5.565.000,00. \\
\hline
\end{tabular}


2. The basis for the critical reviews of the functioning of the protected areas is a fear of difficulties associated with land development opportunities in terms of new investments, infrastructure, building development, usage and management of the site.

3. The benefits to the commune and its inhabitants resulting from the ownership of protected areas refer to the possibility of receiving payments under environmental programs, the creation of agri-tourist farms, investments in tourist infrastructure and the promotion of the commune.
4. According to the communes' thesis - protected areas generate financial losses for the commune and its inhabitants. Losses are several times higher than the profits. The calculations may be flawed but it is apparent that conservation costs and we need to consider who should bear the costs. The solution to this problem could be environmental subsidies from the state budget.

\section{References}

Bołtromiuk, A 2011, 'Wpływ obszarów Natura 2000 na rozwój lokalny w świetle badań' in Zrównoważony rozwój obszarów przyrodniczo cennych, ed T Poskrobko, Wyd. WSE w Białymstoku, pp. 245-260.

Christ, C, Hillel, O, Matus, S \& Sweeting, J 2003, 'Tourism and Biodiversity'. Mapping Tourism's Global Footprint, United Nations Environment Programme, Conservation International, p. 48.

Czarnecki, A 2011, 'Perspektywy rozwoju społecznogospodarczego obszarów wiejskich objętych Siecia Natura 2000 w opinii lokalnych przedsiębiorców' in Uwarunkowania zrównoważonego rozwoju gmin objętych Siecia Natura 2000 w świetle badań empirycznych, ed A Bołtromiuk, Wyd. IRWIR PAN.

Dąbrowski, Z 2013, Kalkulacje i materiały gminy Trzcianne, unpublished.

Jaros, H 2004, 'Uwarunkowania gospodarcze i społeczne gmin, na których obszarze funkcjonuje Narwiański Park Narodowy' in Przyroda Podlasia, ed H Banaszuk, Wyd. Narwiański Park Narodowy, pp. 392-407.
Kuczyńska, M 2009, 'Skutki w planowaniu przestrzennym wynikające z funkcjonowania obszarów Natura 2000 w województwie podlaskim' in Praca dyplomowa, Wyd Politechnika Białostocka, p. 144.

Łuszczyk, M 2011, 'Kierunki rozwoju społeczno-gospodarczego obszarów przyrodniczo cennych' in Zrównoważony rozwój obszarów przyrodniczo cennych, ed T Poskrobko, Wyd. WSE w Białymstoku, pp. 260-277.

Pagiola, S, von Ritter, K \& Bishop, J 2004, 'Assessing the Economic Value of Ecosystem Conservation', The World Bank, Environment Department Paper 2004, no. 101, p. 88.

Pawluśkiewicz, B \& Piekut, K 2011, 'Zarządzanie obszarami Natura 2000 na terenach rolniczych' in Zrównoważony rozwój obszarów przyrodniczo cennych, ed T Poskrobko, Wyd. WSE w Białymstoku, pp. 177-205.

Tederko, Z 2010, 'Rozwój przedsiębiorczości na cennych przyrodniczo obszarach wiejskich', Wieś i Rolnictwo, z. 1, pp. 218-228. 